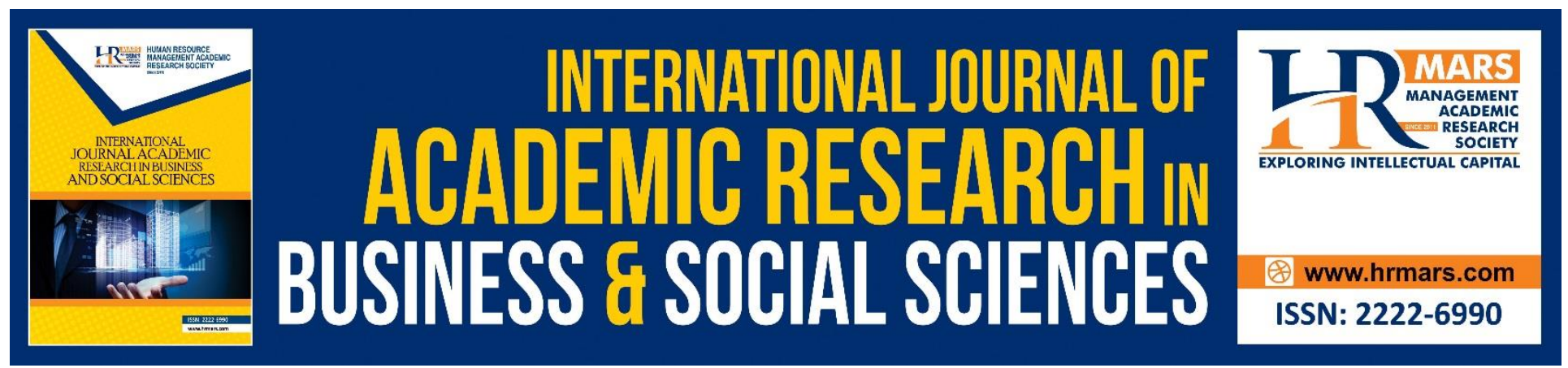

\title{
Sympathy and Benevolence of Business Entities: Evidence during the COVID-19 Pandemic Outbreak
}

Suraiya Ishak, Ahmad Raflis Che Omar, Lokhman Hakim Osman

To Link this Article: http://dx.doi.org/10.6007/IJARBSS/v10-i5/7177

DOI:10.6007/IJARBSS/v10-i5/7177

Received: 09 March 2020, Revised: 12 April 2020, Accepted: 28 April 2020

Published Online: 05 May 2020

In-Text Citation: (Ishak et al., 2020)

To Cite this Article: Ishak, S., Omar, A. R. C., \& Osman, L. H. (2020). Sympathy and Benevolence of Business Entities: Evidence during the COVID-19 Pandemic Outbreak. International Journal of Academic Research in Business and Social Sciences, 10(5), 102-113.

Copyright: (C) 2020 The Author(s)

Published by Human Resource Management Academic Research Society (www.hrmars.com)

This article is published under the Creative Commons Attribution (CC BY 4.0) license. Anyone may reproduce, distribute, translate and create derivative works of this article (for both commercial and non-commercial purposes), subject to full attribution to the original publication and authors. The full terms of this license may be seen

at: http://creativecommons.org/licences/by/4.0/legalcode

Vol. 10, No. 5, 2020, Pg. 102 - 113

http://hrmars.com/index.php/pages/detail/IJARBSS

JOURNAL HOMEPAGE

Full Terms \& Conditions of access and use can be found at http://hrmars.com/index.php/pages/detail/publication-ethics 


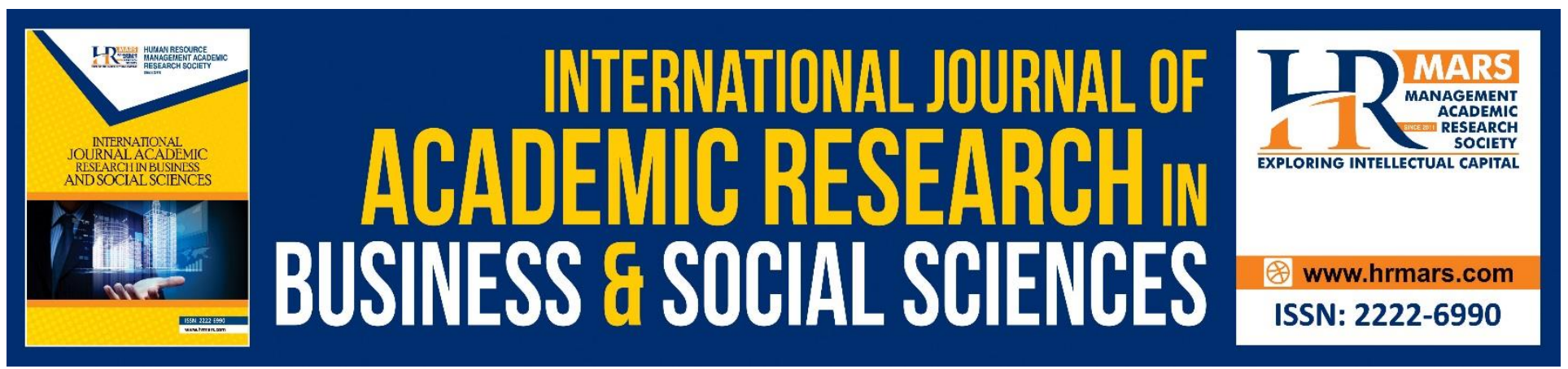

\title{
Sympathy and Benevolence of Business Entities: Evidence during the COVID-19 Pandemic Outbreak
}

\author{
Suraiya Ishak ${ }^{\mathrm{a}}$, Ahmad Raflis Che Omar ${ }^{\mathrm{b}}$, Lokhman Hakim Osman ${ }^{\mathrm{b}}$ \\ ${ }^{a}$ Faculty of Social Science and Humanities, National University of Malaysia, Bangi, Malaysia, ${ }^{\mathrm{b}}$ Faculty \\ of Economics and Management, National University of Malaysia, Bangi, Malaysia \\ Email: raflis@ukm.edu.my
}

\begin{abstract}
This study aims to validate the existence of "rational sympathy" and "universal benevolence" prescribed by Smith's Moral Sentiment Theory among business entities during the COVID-19 pandemic outbreak. The study has optimized the qualitative analysis on secondary data to gain an introspective pertaining to the objectives. The analysed subjects consist of the news reporting on the action taken by particular business actors during the pandemic outbreak and movement order control. The material are analysed in terms of the prescribed dimensions comprise of voluntary-based action, non-reciprocal giving and aim the good cause of society. The findings indicate that rational sympathy and universal benevolence do exist within the current context of business environment. The business participants' rational sympathy and self-interest motive has benefited the society through the offering a wide range of products and services during the normal situation and tranquillity context. Nevertheless, in the highly agitated and disturbance context, the business players resort to universal benevolence motive, thus giving their utmost priority to the greater interest of the state and sovereignty.
\end{abstract}

Keywords: Business, Ethics, Moral Sentiment Theory, COVID-19, Economy

\section{Introduction}

Smith Moral Sentiment Theory proposed that human economic activity should stand on the moral sentiments known as rational sympathy and universal benevolence (Smith 1991). Nevertheless, most proponents of Smith market theory ignored the main thrust of sentiment theory in deliberating human economic behaviours. As such, utility becomes main consideration in evaluating the appropriateness of business behaviours, which are against the actual idea of Smith (1991). Moreover, Milton Friedman's idea of profit maximization became the focal point of all businesses and to certain extent succumbed other considerations from business operations (Friedman 2002; Adewole \& Ginah 2020). The benchmark of business success is largely dominates by profit maximization, thus sweeping the moral values from business considerations (Friedman, 2002). Ethics and morality became alien to 
business matters and to certain extent are the least important to be considered in business matters (Adewole \& Ginah 2020; Septianto et al. 2020; Darwish, Ahmed, \& Pahi, 2020).

Although there are efforts to re-install humanities and ethical values in business insisted in the concept of corporate social responsibility and social responsiveness, the idea is relatively secondary and sometimes merely taken as an instrument to achieve profit-oriented objectives through the increase of future sales or to redeem the tax privileges. For instance, the social responsibility was conducted to develop a positive image for the company or to serve as the remarkable marketing proposition in the launching of a new product (Adewole \& Ginah, 2020). In reality, the market remains a precarious and cruel place with opportunist players acting brutality towards others due to exaggerating of self-interest motives (Woods \& Christodoulidou, 2013; Gino, 2015; Askew et al. 2015; Maseko, 2017). Cheating, deception, organizational misconduct, and many other forms of unethical behaviour are becoming norms in today's business environment.

Besides that, according to Gino (2015), there is a growing body of research in the area of behavioural ethics and moral psychology that shows people who appear to have concern about morality - can and often do bad things when they have chance to cheat. Similarly, the occurrence of corporate frauds has reiterated the rampant scenario among corporate agents or corporate management team (Cossin \& Caballero, 2014; Bezemer et al. 2014; Adewole \& Ginah, 2020). As a result, Agency Theory becomes dominant theory in corporate governance studies aiming to understand various conflicts of interest between the agent (management team) and the principals (shareholders) (Keay, 2017). The Agency Theory holds that all agents are opportunists that need close monitoring through various control mechanisms (Keay, 2017; Vargas-Hernândez \& Cruz, 2018). On the contrary, the Stakeholders Theory holds that corporations must balance the interest of all relevant stakeholders and certain measures are required to restore the rights of all stakeholders (Keay, 2017). The explanation of those theories reflects one critical thing, which is the deterioration of moral values in market rules of games and its participants.

As a result, such conditions ponder a question whether the moral sentiments inspired by Smith in his Moral Sentiment Theory have really gone extinct in the latest COVID-19 outbreak and turbulent business environment? This objective of this study is to validate the existence of moral sentiments, namely the "rational sympathy" and "universal benevolence", among business entities during the COVID-19 pandemic outbreak. This paper explores the issues by picking up the evidence from real experience of business entities during the current pandemic outbreak, business slowdown and movement control order period. We emphasize on two sentiments aspect of Smith Moral Sentiment Theory, which are rational sympathy and universal benevolence. The following section provides an overview on the pandemic and its effect on business sector, which became the framing landscape for the study on the benevolence and sympathy of market players. The third section discuss about the rational sympathy and benevolent of business context of Smith Sentiment Moral Theory. The fourth section describes about the method of study and data. The fifth section presents the discussion and the final section highlights the conclusion of the study.

\section{COVID-19 Pandemic Outbreak and its Effect on Business}

According to the World Health Organization (WHO), COVID-19 coronavirus is an infectious disease caused by a newly discovered coronavirus originating from Wuhan, China (World Health Organization, 2020). The first case of COVID-19 suffering can be trace back to 17 November 2019 and WHO had declared it as pandemic on 11 March 2020 (Davidson, 2020). The virus outbreak is 
INTERNATIONAL JOURNAL OF ACADEMIC RESEARCH IN BUSINESS AND SOCIAL SCIENCES

Vol. 10, No. 5, May, 2020, E-ISSN: 2222-6990 @ 2020 HRMARS

moving quickly and according to the statistical data by Worldometer on 11 April 2020, the virus has infected at least 1.699 million and killed 102,742 people across the world. Based on the Worldometer (2020) real time coronavirus statistics, all the countries have been recording an increased number of infected cases and deaths throughout this period of observations. Table 1 shows the updates pertaining to the attack of COVID-19 in top 15 countries according to the highest number of infected cases.

The current phenomenon is almost rare as it hits almost all countries in the world. Due to the fast spreading pandemic in all countries, each country currently takes serious pre-emptive effort like lockdown, confinement, movement control and social distancing policy to slow the spreading of the virus. Thus, the pandemic effect is enormous as it does not merely affect global population health but also has tremendous effect on the social, business and economy. The norms of the people throughout the world are expected to change due to COVID-19. For instance, in order to fight against the virus, one of the significant approaches is to restrict many of the normal practices and customs people used to have before. As far as moral sentiment is concerned, the pandemic is also expected to enlighten the moral sentiments of the business sectors.

Table 1:

COVID-19 Case Updates as on 11 April 2020

\begin{tabular}{llll}
\hline No & Country & Cases & Death \\
\hline $\mathbf{1 .}$ & United States of America & 502,876 & 18,747 \\
$\mathbf{2 .}$ & Spain & 158,273 & 16,081 \\
$\mathbf{3 .}$ & Italy & 147,577 & 18,849 \\
$\mathbf{4 .}$ & France & 124,869 & 13,197 \\
$\mathbf{5 .}$ & Germany & 122,171 & 2,736 \\
$\mathbf{6 .}$ & China & 81,953 & 3,339 \\
$\mathbf{7 .}$ & United Kingdom & 73,758 & 8,958 \\
$\mathbf{8 .}$ & Iran & 68,192 & 4,232 \\
$\mathbf{9 .}$ & Turkey & 47,029 & 1,006 \\
$\mathbf{1 0}$ & Belgium & 26,667 & 3,019 \\
$\mathbf{1 1 .}$ & Switzerland & 24,551 & 1,002 \\
$\mathbf{1 2}$. & Netherland & 23,097 & 2,511 \\
$\mathbf{1 3 .}$ & Canada & 22,148 & 569 \\
$\mathbf{1 4}$. & Brazil & 19,943 & 1,074 \\
$\mathbf{1 5 .}$ & Portugal & 15,472 & 435 \\
\hline
\end{tabular}

Source: Extracted from Worldometer (2020): Real-time world coronavirus statistics

Stringent government response to curb the virus is deem necessary, but business sector will inevitably impacted in short and medium term horizon. The lockdown, social distancing and movement order control involved closure of all government, private and business premises except those involved in essential services (The New Straits Times, 2020). In non-essentials industry, millions of workers was still under confinement and businesses was in short supply or in shutdown mode. Affected companies are expected to be struggling to get back on normal track (Smith-Bingham \& Hariharan, 2020). The companies in essentials industry are also facing the problems of supply chain continuity in terms of limited raw material supplies, rising costs of raw materials, transportation 
inefficiency and limited numbers of workers allowed to work for the purposes of keeping good social distancing measures (Smith-Bingham \& Hariharan, 2020).

The effect of business could result in certain behaviour in business conducts during economic crisis and economic constraint period. Business entity will freely act ethically due to values and beliefs about what is right and what is wrong (Skinner, 2019). Spirit of sympathy and social responsibility for business sustainability or social responsiveness should also go voluntarily beyond those required to keep within the law for business activities (Skinner, 2019). Contrary, others are arguing the morality of business entity is hinder by their obliged objective in maximizing profit for its owner (Friedman, 2002; Adewole \& Ginah, 2020). This implies that business entities are subject to moral value judgement on their activities and conducts during the crisis period.

\section{Smith Moral Sentiment Theory}

Adam Smith was known for his distinguished masterpieces of the Theory of Moral Sentiments (1759) and The Wealth Nation (1776). The Theory of Moral Sentiments provides a base for the ennobling of man's nature, while The Wealth of Nations deliberates the political-economic framework, which individuals could prosper materially and morally (Herbener, 2002). Both thinking is actually closely related to one another, as the latter must be interpreted in light of the previous assumption. In other words, the Moral Sentiment Theory is the basic rules of human activities including economic behaviours (Smith, 1991). Nevertheless, the Moral Sentiment Theory is ignored by most proponents of Smith's idea in The Wealth of Nations (1776). Thus leading to interpretation that does not fit the original intention of Smith Wealth of Nation idea (Gramp, 1984). For example, in his statement on the beauty of utility, it is not a straightforward to assume that utility is the principle to judge righteousness of an action as Smith quote:

".... But still I affirm that it is not the view of this utility or hurtfulness which is either the first or principal source of our approbation and disapprobation. These sentiments are no doubt enhanced and enlivened by the perception of the beauty or deformity which results from this utility or hurtfulness. But still, I say, they are originally and essentially different from this perception"

Based on the quotation, it is understood that utility (which described as the differences between collective benefits and collective costs for particular action/decision) is not the approbation benchmark as Smith continue with his statement as:

"For first of all, it seems impossible that the approbation of virtue should be a sentiment of the same kind with that by which we approve of a convenient and well-contrived building; or that we should have no other reason for praising a man than that for which we commend a chest of drawers ..."

According to Smith (1991), human beings are moral creatures by nature. Thus, humans can feel the misery of others and can strive for a morally perfect life (Macfie, 1959). This emotion is known as sympathy. He further describes rational sympathy as the beneficial propriety emotion that leads humans to relieve the misery of other people. It would be meaningless if a person merely expressed sympathy to another person but never proceeded with any action to help the person in need (Smith, 1991; Adewole \& Ginah, 2020). Rational sympathy is achieved through reasoning in a specific context. This means that the individual needs to put themselves in the other person's shoes to initiate the feeling of rational sympathy. The person would proceed with actions to mitigate the 
INTERNATIONAL JOURNAL OF ACADEMIC RESEARCH IN BUSINESS AND SOCIAL SCIENCES Vol. 10, No. 5, May, 2020, E-ISSN: 2222-6990 @ 2020 HRMARS

burden of others, which simultaneously aligns with his/her own private beliefs. Thus, the sympathetic behaviour is in line with human self-interest. It recognizes self-interest while also recognizing others' interest.

Based on Moral Sentiment Theory, the real joy is to watch other people feel happy through the choice of decisions/actions taken by the particular person (Smith, 1991). As a result, the concept of economic man will be in parallel with the concept of a prudent man. The economic man assumes human beings are rational, thus they will align their conduct to the expectations of potential customers and society. This will assure their long term profit and survival. Due to self-love, business owners will be prudent in their actions to be accepted by stakeholders within his operational background. Hence, the business people will compete with each other to provide services to satisfy the stakeholder expectations due to their self-love. Finally, this brings an advantage to the customers and society in general, due to more choices and quality offered in the market.

As far as benevolent is concerned, according to Smith, the benevolent of businessman is indirectly practiced (Smith, 1991). Although indirectly existing, the benevolent which operationalised through the "self-interest" and "self-love", inevitably benefit the society or the public. This is in conjunction with the famous quote of Adam Smith on the concept of benevolence within the context of free market and capitalist system (Book 1-Chapter 2 The Wealth of Nation):

"It is not from the benevolence of the butcher, the brewer, or the baker that we expect our dinner, but from their regard to their own interest. We address ourselves, not to their humanity but to their self-love, and never talk to them of our own necessities but of their advantages. Nobody but a beggar chooses to depend chiefly upon the benevolence of his fellow-citizens. Even a beggar does not depend upon it entirely...."

Benevolence of the capitalist means to see others' satisfaction from the delivered product/services (Smith, 1991). In order to satisfy the customers, each seller within the perfect competition environment is forced to supply whatever the customers want, to reduce the price of goods as possible and other strategies meant to attract the customers attention (Skinner, 2019; Septianto et al. 2020). Eventually, this situation brings advantages to the customers and society (pursuit of other people's interest). Meanwhile, due to the customer's satisfaction, the profit of the business will now increase (pursuit of self-interest). Hence, self-interest and self-love become the push factors that force sellers to satisfy the needs of the customers in the best way.

On top of that, Smith further elaborates the chapter on Universal Benevolence (Smith, 1991). As far as self-interest is concerned, a wise and virtuous man is at all times willing that his own private interest to be sacrificed for the public interest of his own particular order or society. Hence, it is understood that self-interest is not the underlying cause in all conditions. There is an exception whereby the businessmen voluntarily choose to sacrifice their self interest for the sake of the public (Septianto et al. 2020). Additionally, Smith mentions that the interest of this order or society should be sacrificed to the greater interest of the state or sovereignty, of which it is only a subordinate part.

Finally, Smith states that all those inferior interests should be sacrificed to the great interest of the universe, to the interest of that great society of all sensible and intelligent things, of which God himself is the immediate administrator and director (Smith, 1991). This reflects that mankind including businessman are rational beings who are willing to forgo self-interest for the sake of greater interest of the society and ultimately for the higher interest that controls the entire universe. 
INTERNATIONAL JOURNAL OF ACADEMIC RESEARCH IN BUSINESS AND SOCIAL SCIENCES

Vol. 10, No. 5, May, 2020, E-ISSN: 2222-6990 ㄷ 2020 HRMARS

Therefore, a specific study is necessary to deliberate the existence of such ideal sentiment in a real life context within current business context.

\section{Method}

This study employs secondary data, which consist of archives of official reports about the action taken by the business actors during the COVID-19 pandemic outbreak. The report consists of news reporting the action of particular entities in terms of promoting humanities agenda. Based on the report and news, we identify whether the actions are consistent with the rational sympathy and benevolent sentiment described under Smith Moral Sentiment Theory. The benevolent is operationalize through the reflection of these criteria:

i. Voluntary-based action.

ii. A one-way type of giving and not reciprocal (the giving is not due to certain reward or obligation from the recipients).

iii. The giving is for the good cause of the public/country.

The report and news were collected from 15 March 2020 to 14 April 2020. The period is selected because at that particular point of time, the total coronavirus cases had soar skyrocketed and severely hit peoples in more than 170 countries reported by Worldometer (2020) as depicted in Table 1. The article's content is analysed through the latent content of the text.

\section{Data}

This part presents the main content extracted from the selected articles.

\section{Case 1}

The shortage of personal protective equipment (PPE) and other medical devices became one of the biggest problems dogging the Italian health system since the contagion surfaced in the wealthy northern region of Lombardy at the end of February 2020. As a result, fashion group Armani Italian production plants start producing single use medical overalls, in an effort to support Italian healthcare workers in the coronavirus crisis. The fashion house, run by designer Giorgio Armani, had increased donations up to 2 million euros (1.82 million pounds), from an initial 1.25million euros, which donated to Italian hospitals to help them facing the virus emergency. Besides that, a consortium of Italian textile and fashion companies, coordinated by business association Confindustria Moda, is expected to start producing millions of protective facemasks, with the aim of making Italy self-sufficient in manufacturing the masks.

Source: Reuters (2020)

Published on 27 March 2020

\section{Case 2}

UK manufacturers such as Vauxhall and Airbus planned the 3D-print parts for ventilators to treat coronavirus patients, as part of the effort to build thousands of medical devices. As such, Vauxhall would free up the plant capacity to make ventilators. Besides that, other firms including Rolls-Royce and the UK's largest carmaker, Jaguar Land Rover, have ready to assist the push to make ventilators in any way they can. On top of that, a group of British manufacturers began producing the medical ventilators for the NHS under the twin codenames Project Oyster and Project Penguin. The Ventilator Challenge UK, represents a consortium of 14 firms including Airbus and Rolls-Royce. The project 
INTERNATIONAL JOURNAL OF ACADEMIC RESEARCH IN BUSINESS AND SOCIAL SCIENCES

Vol. 10, No. 5, May, 2020, E-ISSN: 2222-6990 ㄷ 2020 HRMARS

began after the government ordered 10,000 of the devices to treat coronavirus patients. It is reported that the government has 8,175 ventilators but has turned to British industry to produce 30,000 in a week to combat the unexpected surge of new cases in the United Kingdom.

Source: Davies, $(2020 a, b)$

Published on 17 March 2020; 29 March 2020

\section{Case 3}

Malaysian government-linked companies (GLCs), government-linked investment companies (GLICs) and the private sector have contributed RM51.5million to GLCs/GLICs Disaster Response Network (GDRN). The contributions are being used to support the Ministry of Health (MoH) in a coordinated and streamlined manner to buy medical supplies in fight against the COVID-19 pandemic. Of the RM51.5million, RM42.6million has been allocated to support MoH to purchase medical supplies; while RM8.9million was spent on various humanitarian aid assistance for families, front liners and stranded university students.

Source: Aman (2020)

Published on 2 April 2020

\section{Case 4}

Bacardi is a company of liquor manufacturer. The report stated that Bacardi has produced 70,000 litres of hand sanitizers, which will be distribute primarily to government district hospitals, to help mitigate the spread of coronavirus pandemic in India. The company has started production of hand sanitizers at its co-packing facility in Telangana. The effort is part of Bacardi's commitment to help produce more than 267,000 gallons (1.1million litres) of hand sanitizer worldwide in order to fight the pandemic. Besides that, Bacardi-owned manufacturing sites across the United States, Mexico, France, England, Italy, Scotland and Puerto Rico are already part of this effort. The company facilities will make use of alcohol in stock, and has also set aside designated quantities of alcohol, in order to fulfil the critical demand for hand sanitizer for combating COVID-19.

Source: The Economic Times (2020)

Published on 6 April 2020.

\section{Case 5}

Louis Vutton (LVMH) has used its perfume production lines to make hand sanitiser to protect people against the virus. The effort is taken due to the nationwide shortage of the anti-viral products across France amid the pandemic. Louis Vutton (LVMH) is set to produce around 12 tons of hand sanitizer a week, which will be deliver to 39 public hospitals in Paris without any charge.

Source: Caruso (2020)

Published on 17 March 2020

\section{Discussion}

This study aims to investigate the existence of moral sentiment among business players, which has long been stigmatize with profit maximization and selfish motives. The justification for this study is to validate the existence of "rational sympathy" and "universal benevolence" among the business entities in a real life context. As far as universal benevolence is concerned, an action that is voluntarybased, irreciprocal and aims for the good cause of the public found existing in the observed 
environment. To a certain extent the business owners actions are not guided by the "self-interest" albeit the profit maximization. They are able to demonstrate a sort of moral sentiment of pure benevolence as Smith described as "... that the interest of this order or society should be sacrificed to the greater interest of the state or sovereignty, of which it is only a subordinate part". Thus, the cases prove a condition in which the interests of state and sovereignty have taken place of self-interest and self-love. This is understood from Case 3, 4 and 5 in which all the cases have given commitment to sacrifice their company resources for the sake of society/country needs without reciprocal demand.

Besides that, as depicted in Case 1 and 2, it shows that there is serious effort by the industry players to aggressively fulfil the overwhelming need for the health treatment equipment. Additionally this study proves the existence of universal benevolence in a critical situation such as the COVID-19 pandemic outbreak. Based on the cases, the corporate and business owners have reacted upon the non-self-interest motives in situations of immense destruction to public health or human life. This finding shows that men are moral creatures, thus their institutions are also able to exercise noble benevolence to the society. The threat of pandemic that affects all countries has united the world including business owners to give their noble service to the nation by utilizing the resources and assets that they have. The companies are willing to make use of their internal resources and capacities to produce critical necessities such as hand sanitizer, facemask, personal protective equipment (PPE), and ventilators. Even though they may still charge prices on the items sold to the public, it is still in parallel with the sentiment of rational sympathy.

The items desperately needed to combat the COVID-19 and the willingness of the sellers/manufacturers to produce the items is actually a noble reaction according to the principle of rational sympathy. In a situation whereby the facemask is unavailable or the ventilator is insufficient to cover the need of thousand patients who are critical, there must be a group of businesspeople who are willing to take responsibility and to accept all risks to produce the item, by all means. The group's willingness to produce the needed services or products, for whatever motive they may have including pursuit of self-interest, should not undermine the benefit the society would obtain from such production. The scenario resembles a win-win situation for respective parties in parallel with Smith's famous quotation of:

"It is not from the benevolence of the butcher, the brewer, or the baker that we expect our dinner, but from their regard to their own interest. We address ourselves, not to their humanity but to their self-love, and never talk to them of our own necessities but of their advantages. Nobody but a beggar chooses to depend chiefly upon the benevolence of his fellow-citizens. Even a beggar does not depend upon it entirely...."

However, as mentioned earlier, to certain extent, some companies may even forgo their selfinterest by putting the interest of people and the country as the first priority. As such, the companies resort to the universal benevolence sentiment, which reflected through the offering of free service/products or by donating valuable resources merely for the sake of the public and the country. To wrap up, we conclude that moral sentiment namely the "rational sympathy" and "universal benevolence" actually exist in the real business world and it has surfaced during the immense destructive situation such as the COVID-19 pandemic. Thus, it reflects the pragmatic of Adam Smith idea constructed through his Moral Sentiment Theory. 


\section{Conclusion}

Based on this study, the business "self-interest" motive has benefited the society through the offering a wide range of products and services during normal situation or tranquillity. As such Smith expression of "it is not from the benevolence of the butcher, the brewer, or the baker that we expect our dinner, but from their regard to their own interest" is prove to be true to describe motives of economic activity persist in the normal scenario. Nevertheless, in a highly agitated and disturbance context, the businesses have resort to "universal benevolence" motive, thus giving priority to "the greater interest of the state or sovereignty" to subordinate the individual self-interest. The business players show an inclination towards behaviour, which is non-reciprocal and have concern on the need of the country and society in the time of COVID-19 pandemic outbreak. The execution of rational sympathy by the offering of highly needed products or services to fulfil the needs of the agitated context is also recognize as "for the good cause of society". As long as the offering price within reasonable range, the action able to provides goodness for the society as portrayed in the critical demand for facemasks and hand sanitizer to protect against the virus.

As far the finding is concern, this study provides a preliminary basis for future studies to perform quantitative study to generalize the phenomenon to a larger population context. This study provides evidence that moral sentiments exist within the context of business entities. Future researchers who interested in studying moral sentiments of universal benevolence among business entities should take into consideration a real agitated situation, such as the COVID 19 outbreak, instead of relying on hypothetical scenarios in the measurement of ethical (unethical) response. The inclusion of a real agitated situation acts as the "living incubator" that provides relevant atmospheres or stimulus to drive spontaneous and accurate response from the respondents. Additionally, future studies can execute comparison studies to understand the probable variation of moral sentiments among business entities across different contexts, such as between countries; cultures; and business ownerships. The suggestion is largely due to the reason that different contexts may produce dissimilar inclination of moral sentiments among the business entities. As far as policy implication is concern, the findings offer important insight that moral sentiment of the business entities appear differently according to situations. In a normal context, the business entities are more attracted to the "self-love" rewards inevitably translated into the profit maximization objective. As such, to stimulate compliance behaviours from the business participants, the policy order should be delivered in terms of its impact on "their self-love motive". Meanwhile, in a critical agitated situation, business entities are willing to subordinate their "self-interest" to the "greater interest of the state or sovereignty", thus the policy order should communicate the impact (benefit) of their actions to resolve the needs of the state.

\section{References}

Adewole, A., Ginah, G. O. (2020). Appraisal of perspectives to morality in business: towards developing effective operational mindsets for business practitioners. Advances in Social Sciences Research Journal, 7(1), 24-34.

Aman, A. S. (2020). GLCs, GLICs contribute RM51.5mil to COVID-19 fund. New Straits Times. April, 2. https://www.nst.com.my/business (access on 8 April 2020).

Askew, O. A., Beisler, J. M., Keel, J. (2015). Current trends of unethical behaviour within organizations. International Journal of Management and Information Systems, 19(3), 107-114. 
INTERNATIONAL JOURNAL OF ACADEMIC RESEARCH IN BUSINESS AND SOCIAL SCIENCES

Vol. 10, No. 5, May, 2020, E-ISSN: 2222-6990 @ 2020 HRMARS

Bezemer, P. J., Peij, S., de Kruijs, L., Maassen, G. (2014). How two-tier boards can be more effective. Corporate Governance, 14(1), 15-31.

Caruso, C. (2020). The Company Behind Louis Vuitton Is Now Making Hand Sanitizer for French Hospitals. March, 17. https://www.globalcitizen.org (access on 8 April 2020).

Cossin, D., Caballero, J. (2014). A Practical Perspective: The four pillars of board effectiveness. IMD Global Board Center. https://www.researchgate.net/publication (access on 2 March 2020).

Davidson, H. (2020). First Covid-19 Case Happened in November, China Government Record ShowReports. 13 March. https://www.theguardian.com/world (access on 2 April 2020).

Darwish, S., Ahmed, U., \& Pahi, M. H. (2020). Innovative Work Behavior During COVID-19 for Medical Representative in the Pharmaceutical Industry: Test of a Moderation Model in Bahrain. International Journal of Pharmaceutical Research. 12(4), 19271934. doi.org/10.31838/ijpr/2020.12.04.277

Davies, R. (2020a). UK manufacturers to re-gear factories to build ventilators for NHS. The Guardian. March, 17. https://www.theguardian.com/business (access on 8 April 2020).

Davies, R. (2020b). Ventilator Challenge UK to start production in Covid-19 fight. The Guardian. March, 29. https://www.theguardian.com/world (access on 9 April 2020).

Friedman, M. (2002). The social responsibility of business is to increase profits. In. Donaldson, T., Werhane, P.H. \& Cording, M. (Ed.). Ethical Issues in Business: A Philosophical Approach. Upper Saddle New Jersey: Prentice Hall, pp. 33-38.

Gino, F. (2015). Understanding ordinary unethical behavior: why people who value morality act immoral. Current Opinion in Behavioral Sciences, 3, 107-111.

Gramp. W. D. (1984). Adam Smith and the economic man. Journal of Political Economy. 56, 315336.

Herbener, J. (2002). An integration of the Wealth of Nations the Theory of Moral Sentiments. The Journal of Libertarian Studies. VIII(2), 276-288.

Keay, A. (2017). Stewardship Theory: is board accountability necessary? International Journal of Law and Management, 59(6), 1292-1314.

Macfie, A. L. (1959). Adam Smith's moral sentiments as foundation for his Wealth of Nations. Oxford Economics Papers, 11, 209-228.

Maseko, C. M. (2017). Literature on theory and practice on unethical practices in the construction of projects: a case of an emerging economy. Risk Governance and Control: Financial Market \& Institutions, 7(4-2), 214-224.

Reuters. (2020). Italy's Armani converts fashion sites to produce medical overalls. March, 27. http://english.astroawani.com/world-news (access on 2 April 2020).

Septianto, F., Tjiptono, F., and Arli, D. (2020). Authentically, proudly ethical: The effects of authentic pride on consumer acceptance of unethical behaviour. European Journal of Marketing, 54(2), 351-379.

Skinner, H. (2019). The impact of cultural values and economic constraints on tourism businesses' ethical practices. International Journal of Tourism Cities, 5(2), 169-187.

Smith, A. (1991). The Theory of Moral Sentiments. New York: Oxford University Press.

Smith-Bingham, R., \& Hariharan, K. (2020). This is the impact of the Coronavirus on business. World Economic Forum. Retrieved from https://www.weforum.org/agenda (access on 9 April 2020). 
INTERNATIONAL JOURNAL OF ACADEMIC RESEARCH IN BUSINESS AND SOCIAL SCIENCES

Vol. 10, No. 5, May, 2020, E-ISSN: 2222-6990 @ 2020 HRMARS

The Economic Times. (2020). COVID-19: Bacardi to produce 70,000 litres of hand sanitizers. 6 April. https://economictimes.indiatimes.com/industry (access on 9 April 2020).

The New Straits Times. (2020). COVID-19: Movement Control Order imposed with only essential sectors operating. March, 16. https://www.nst.com.my/news (access on 9 April 2020).

The Star. (2020) Covid-19: Current situation in Malaysia. April, 12. https://www.thestar.com.my/news (access on 13 April 2020).

The Theory of Moral Sentiments by Adam Smith. (1975). https://www.marxists.org/reference/archive. (access on 6 April 2020).

Vargas-Hernândez, J. G., Cruz, T. M. E. (2018). Corporate governance and Agency Theory: Megacable case. Corporate Governance and Sustainability Review, 2(1), 59-69.

Woods, M., Cristodoulidou, N. (2013). Unethical business practices in the food industry. Journal of Foodservice Business Research, 16, 407-419.

World Health Organization. (WHO). (2020). https://www.who.int/health-topics (access on 7 April 2020).

Worldometer. (2020). COVID-19 Coronavirus Pandemic. https://www.worldometers.info (access on 13 April 2020). 